NOTE

\title{
Effect of salinity on transmission of necrotizing hepatopancreatitis bacterium (NHPB) to Kona stock Litopenaeus vannamei
}

\author{
Amanda G. Vincent, Jeffrey M. Lotz* \\ Department of Coastal Sciences, The University of Southern Mississippi, Gulf Coast Research Laboratory, PO Box 7000 , \\ Ocean Springs, Mississippi 39566-7000, USA
}

\begin{abstract}
Elevated salinity and temperature have been observed prior to devastating necrotizing hepatopancreatitis (NHP) outbreaks in several geographically isolated shrimp ponds. These observations have led to the hypothesis that the NHP-bacterium (NHPB) is hindered by reduced salinity, even though the mechanism is not understood. The objective of this research was to examine the effect of salinity on transmission of NHPB. The transmission rate of NHPB was estimated through laboratory experiments whereby individuals of Kona stock Litopenaeus vannamei were orally exposed to a dead NHPB-infected shrimp. For each replicate, 12 susceptible shrimp were placed with a dead NHPB-infected shrimp in a $1 \mathrm{~m}^{2}$ bottom area cylindrical tank maintained at $30^{\circ} \mathrm{C}$ for a period of $24 \mathrm{~h}$. Four salinities of 10, 20, 30, and 40\% were replicated 2 times in 2 trials, giving a total of 192 shrimp exposed per os to infective material. In each trial, a negative control group was included at each salinity, giving a total of 96 shrimp exposed orally to uninfected material. After the $24 \mathrm{~h}$ exposure period, susceptible shrimp were individually isolated at the same physical conditions for up to $60 \mathrm{~d}$ to determine NHPB transmission. The NHPB was transmissible regardless of salinity: nearly a quarter of susceptible shrimp exposed to NHPB at the lowest $(10 \%)$ and highest $(40 \%)$ salinity examined acquired NHPB. Transmission rates were highest at the intermediate salinities of 20 and $30 \%$, suggesting that those salinities are optimal for NHPB transmission. The observed association between high salinity and NHP outbreak in a shrimp pond is not explained by these results because reduced transmission occurred at very low and very high salinities.
\end{abstract}

KEY WORDS: NHP-bacterium · Environmental stress $\cdot$ Shrimp aquaculture $\cdot$ Management

Resale or republication not permitted without written consent of the publisher

\section{INTRODUCTION}

Necrotizing hepatopancreatitis bacterium (NHPB) is a gram-negative Alphaproteobacterium that can cause up to $95 \%$ mortality in affected shrimp aquaculture ponds (Johnson 1990, Lightner 1996). The NHPB is pleomorphic, present as a smaller rod and a larger flagellated helical form (Krol et al. 1991, Frelier et al. 1992, Lightner et al. 1992). This bacterium is obligately intracellular, residing in the cytoplasm of hepatopancreas epithelial cells. Gross signs of early NHPB infection include reduced feed intake, lethargy, and an empty gastro-intestinal tract. Severe late-stage infections exhibit atrophy and discoloration of the hepatopancreas, and characteristic granulomatous-like lesions of the hepatopancreas tissue (Frelier et al. 1992, Lightner 1996). NHP disease has primarily affected cultured penaeids in the Americas, and reported host species include Litopenaeus vannamei, L. setiferus, L. stylirostris, Farfantepenaeus aztecus and F. californiensis (Lightner 1996).

Salinity and temperature are environmental factors thought to greatly influence the occurrence of NHP outbreaks in penaeid shrimp aquaculture. Initial NHP 
outbreaks in Texas, USA, were associated with temperatures from 29 to $31^{\circ} \mathrm{C}$ in salinities of 20 to $40 \%$ o (Frelier et al. 1992). An epidemic of NHPB in Peru was linked to high temperatures of 29 to $35^{\circ} \mathrm{C}$, and elevated salinities of greater than 30 to $38 \%$ preceded the outbreaks for periods of several weeks (Lightner \& Redman 1994). In addition, NHPB outbreaks in Venezuela, Brazil, Ecuador, Costa Rica, and Panama from 1993 to 1995 followed physical conditions similar to those encountered in Texas, USA, and Peru (Lightner 1996).

Because epidemics of NHPB in shrimp ponds have been observed following periods of elevated salinity and temperature, a strategy for managing NHP disease has been to reduce salinity in aquaculture ponds (Frelier et al. 1994, 1995, Jory 1997). However, we cannot say for certain that salinity is the determining factor that produces conditions favorable for NHP outbreaks. Thus, a better understanding of the relationship between salinity and NHP disease is greatly needed. In this study, we examine the effect of salinity on transmission of NHPB in experimentally infected Kona stock Litopenaeus vannamei in an effort to elucidate the role of salinity in NHP outbreaks.

\section{MATERIALS AND METHODS}

Experimental design. Trial 1: Four salinity treatments of $10,20,30$, and $40 \pm 2 \%$ were each replicated 3 times, giving a total of 12 treatments. The 3 replicates at each salinity consisted of 2 replicates in which susceptible shrimp were orally exposed to a dead NHPB-positive shrimp and 1 replicate in which susceptible shrimp were exposed to an uninfected dead shrimp. A total of 12 cylindrical tanks of $1000 \mathrm{l}$ volume and $1 \mathrm{~m}^{2}$ bottom surface area were filled to approximately $10 \mathrm{~cm}$ with artificial Crystal Sea ${ }^{\circledR}$ Marinemix seawater prepared from reverse osmosis filtered water. The assignment of salinity and exposure of NHPB-positive or -negative control was randomized for each replicate. The exposure protocol followed Soto et al. (2001). A total of 144 susceptible juveniles of Kona stock Litopenaeus vannamei (Pruder et al. 1995, Lotz et al. 2003) (mean weight $12.1 \pm 0.2 \mathrm{~g}$, range 6.8 to $18.3 \mathrm{~g}$ ) were divided into 12 cylindrical tanks, giving a total of 12 shrimp in each tank. The density of 12 shrimp $\mathrm{m}^{-2}$ is comparable to mean densities of $L$. setiferus in wild populations (Zimmerman \& Minello 1984, Soto \& Lotz 2001). In order to reduce possible variation, all susceptible shrimp in this experiment were male. Shrimp were gradually acclimated over 1 wk from $22 \%$ salinity to appropriate salinities of 10 , 20,30 , or $40 \%$. Cylindrical tanks were aerated and maintained at $30 \pm 2{ }^{\circ} \mathrm{C}$. Susceptible shrimp were fasted $3 \mathrm{~d}$ prior to exposure. Susceptible shrimp were exposed orally (an effective mode of NHPB exposure) to NHPB-infected shrimp (Vincent et al. 2004). Eight shrimp were obtained from a long-term exposure system of NHPB to individuals of Kona stock L. vannamei (Vincent et al. 2004), killed, weighed to nearest $0.01 \mathrm{~g}$, and a small piece of hepatopancreas was excised from the cephalothorax and stored in a $1.5 \mathrm{ml}$ microcentrifuge tube at $-20^{\circ} \mathrm{C}$ for PCR analysis. The weight of the hepatopancreas sample was recorded prior to molecular analysis for detection and quantification of NHPB. On Day 0, each of the 8 exposure shrimp were randomly placed into 1 of the 8 cylindrical tanks corresponding to 2 replicates at each salinity. The remaining 4 cylindrical tanks were a negative control for each of the 4 salinities. Four shrimp obtained from a nonNHPB infected shrimp stock were killed, weighed to the nearest $0.01 \mathrm{~g}$, and placed into the appropriate negative control tank for each salinity on Day 0 .

During the $24 \mathrm{~h}$ exposure period for each replicate, susceptible shrimp generally consumed the entire cephalothorax and in most cases the entire carcass. After the $24 \mathrm{~h}$ exposure period, individual shrimp were randomly placed into aerated Sterilite ${ }^{\circledR}$ containers (35 cm length $\times 22 \mathrm{~cm}$ width $\times 12 \mathrm{~cm}$ height) in a total volume of approximately $4 \mathrm{l}$ of artificial seawater maintained at the same salinity as the exposure phase. Shrimp were maintained in a waterbath at $30 \pm 2^{\circ} \mathrm{C}$ for $60 \mathrm{~d}$, and freshwater was added to the individual containers to replace evaporation. Temperature was monitored daily and salinity weekly. Individual shrimp were fed Rangen 45/10 (Buhl) commercial pellets at approximately $5 \%$ body weight every $2 \mathrm{~d}$.

The day of post-exposure mortality was recorded for shrimp that died over the $60 \mathrm{~d}$ period. Moribund and dead shrimp were weighed to the nearest $0.01 \mathrm{~g}$ and cut transversely at the junction of the cephalothorax and abdomen, and a small piece of the hepatopancreas of approximately $25 \mathrm{mg}$ was excised from the cephalothorax and stored in a $1.5 \mathrm{ml}$ microcentrifuge tube at $-20^{\circ} \mathrm{C}$ for molecular detection of NHPB. Shrimp surviving to $60 \mathrm{~d}$ were killed and processed in like manner.

Trial 2: The procedure described in Trial 1 was repeated in Trial 2. Mean weight of the 144 susceptible males of Kona stock Litopenaeus vannamei was $12.8 \pm$ $0.2 \mathrm{~g}$ (range 7.5 to $18.2 \mathrm{~g}$ ).

Diagnostic methods. NHPB in hepatopancreas tissue was extracted and analyzed by PCR (Loy et al. 1996a). Real-time PCR was used to quantify the initial dose of NHPB in hepatopancreas tissue of exposure shrimp, and to quantify lethal load in moribund and dead shrimp (Vincent \& Lotz 2005).

Statistical analysis. For each replicate, the transmission rate of NHPB from a dead infected shrimp $\left(\beta_{d}\right)$ was estimated as the proportion of susceptible shrimp that acquired NHPB after a $24 \mathrm{~h}$ exposure to a dead 
infected shrimp (Soto et al. 2001). Mean $\beta_{d}$ of NHPB at different salinities were compared by ANOVA using Systat version 11.

\section{RESULTS}

\section{NHPB dose in exposure shrimp}

For each replicate, the dose of NHPB in Litopenaeus vannamei exposed to susceptible shrimp was determined through real-time PCR (Table 1). Lethal NHPB loads were identified as being greater than $1 \times 10^{5}$ copies $\mathrm{mg}^{-1}$ hepatopancreas tissue. NHPB dose (expressed as copies $\mathrm{mg}^{-1}$ of hepatopancreas tissue) ranged $2.2 \times 10^{7}$ to $1.3 \times 10^{8}$ for 14 of the replicates. In Trial 2, the initial dose for 1 of the $40 \%$ replicate was moderate at $2.3 \times 10^{4}$ copies $\mathrm{mg}^{-1}$, and no NHPB was detected in the tissue sample for a replicate at $20 \%$.

\section{Transmission rate of NHPB from a dead host $\left(\beta_{d}\right)$}

$\beta_{\mathrm{d}}$ occurred at each salinity (Table 2 ). At the lowest salinity of $10 \%$, NHPB transmission ranged from 1 to 5

Table 1. Dose of necrotizing hepatopancreatitis bacterium (NHPB) (copies $\mathrm{mg}^{-1}$ hepatopancreas tissue) exposed per os to susceptible individuals of Kona stock Litopenaeus vannamei at different salinities. nd: NHPB not detected in tissue sample

\begin{tabular}{|c|c|c|c|c|c|}
\hline \multirow[t]{2}{*}{ Trial } & \multirow[t]{2}{*}{ Replicate } & \multicolumn{4}{|c|}{ NHPB dose (copies $\mathrm{mg}^{-1}$ ) } \\
\hline & & $10 \%$ & $20 \%$ & $30 \%$ & $40 \%$ \\
\hline \multirow[t]{2}{*}{1} & 1 & $2.6 \times 10^{7}$ & $3.5 \times 10^{7}$ & $5.6 \times 10^{7}$ & $1.0 \times 10^{8}$ \\
\hline & 2 & $2.2 \times 10^{7}$ & $3.5 \times 10^{7}$ & $1.3 \times 10^{8}$ & $9.5 \times 10^{7}$ \\
\hline \multirow[t]{2}{*}{2} & 1 & $1.2 \times 10^{8}$ & nd & $6.5 \times 10^{7}$ & $2.3 \times 10^{4}$ \\
\hline & 2 & $3.9 \times 10^{7}$ & $8.7 \times 10^{7}$ & $3.3 \times 10^{7}$ & $7.8 \times 10^{7}$ \\
\hline
\end{tabular}

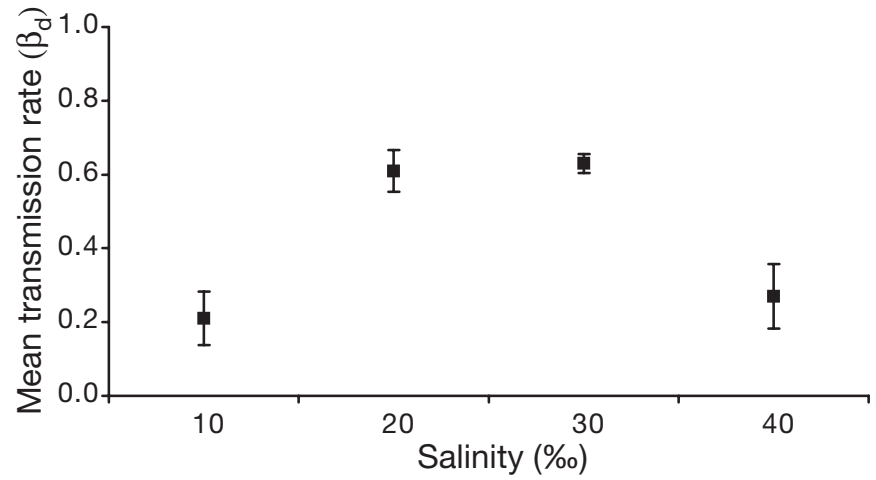

Fig. 1. Mean transmission rate of necrotizing hepatopancreatitis bacterium (NHPB) from a dead infected shrimp $\left(\beta_{\mathrm{d}}\right)$ exposed per os to Kona stock Litopenaeus vannamei at salinities of 10, 20, 30 and 40\% (ANOVA, p = 0.001). Error bars indicate $\mathrm{SE}_{i} \beta_{\mathrm{d}}$ estimated as proportion of susceptible shrimp (of 12) that acquired NHPB infection after exposure to a dead infected shrimp for $24 \mathrm{~h}$

shrimp (of 12 exposed), with a mean $\beta_{\mathrm{d}}$ of 0.21 . At $20 \%$, 6 to 8 shrimp (of 12) acquired NHPB, with a mean $\beta_{\mathrm{d}}$ of 0.61 . Transmission of NHPB at $30 \%$ ranged from 7 to 8 shrimp (of 12), with a mean $\beta_{\mathrm{d}}$ of 0.63 . Transmission at $40 \%$ ranged from 1 to 6 shrimp (of 12) resulting in a mean $\beta_{\mathrm{d}}$ of 0.27 .

Mean $\beta_{d}$ differed significantly among salinities (Fig. 1; ANOVA, $p=0.001$ ). Mean $\beta_{\mathrm{d}}$ was significantly lower at 10 and $40 \%$ than at 20 or $30 \%$, but there was no difference in mean $\beta_{\mathrm{d}}$ between 10 and $40 \%$ or between 20 and $30 \%$. $\beta_{\mathrm{d}}$ increased from $10 \%$ to peak at 20 and $30 \%$ before decreasing at $40 \%$.

\section{DISCUSSION}

Outbreaks of NHP have been linked to periods of elevated salinity and temperature (Frelier et al. 1992, Lightner \& Redman 1994, Lightner 1996). The present study examined the effect of salinity on transmission of NHPB under experimental laboratory conditions. Susceptible shrimp were exposed to dead shrimp carrying lethal loads of NHPB that ranged from $10^{7}$ to $10^{8}$ copies $\mathrm{mg}^{-1}$ hepatopancreas tissue (Vincent $\&$ Lotz 2005). The NHPB was transmissible to juvenile Kona stock Litopenaeus vannamei regardless of salinity. Although the mean $\beta_{\mathrm{d}}$ of NHPB from a dead shrimp was lower at the lowest (10\%) and highest (40\%) salinities, nearly a quarter of susceptible shrimp became infected with NHPB after contact with a dead infected shrimp at 
these low and high salinities. Thus, low (or high) salinity does not appear to stop NHPB transmission by cannibalism.

Transmission of NHPB was highest at 20 and $30 \%$, similar to that previously observed at $30 \%$ and $30^{\circ} \mathrm{C}$ (A. Vincent \& J. Lotz unpubl. data). Because NHPB transmission peaked at intermediate salinity, this suggests an optimal salinity range for NHPB transmission. Additional studies are warranted to examine NHPB transmission below $10 \%$ to see if this holds true.

The results do not explain the observed association between high salinity and NHP outbreaks, because reduced transmission occurred at low as well as high salinities. These results suggest that a correlation between salinity and outbreaks is not explained by transmission alone. However, salinity may affect outbreaks in other ways. In addition, factors such as temperature or reservoir hosts may be involved in an NHP outbreak in a shrimp pond. Although no reservoir host has been reported for NHPB, it has been proposed through molecular phylogeny that epicommensal ciliates may be a part of this bacterium's life cycle (Loy et al. 1996b). Another possibility is that an interaction of several physical characteristics of a shrimp pond creates favorable conditions for NHP outbreaks. While interaction between environmental factors is possible, salinity's effect on transmission alone does not appear to be a determining factor in NHP outbreaks. Although NHPB transmission was lower at reduced salinity, susceptible shrimp were still able to acquire NHPB infection after contact (through cannibalism) with a dead infected shrimp. Because of the dynamics of NHPB infection, the introduction of infected shrimp into a susceptible population of shrimp could produce an NHP outbreak (A. Vincent \& J. Lotz unpubl. data); however, the character of the outbreak could differ at various salinities. Further studies to investigate the effect of salinity and temperature on survival of NHPBinfected shrimp and to identify potential reservoir hosts for NHPB infection in the shrimp pond environment are warranted.

Acknowledgements. We thank V. Breland and M. Turner for technical assistance and 4 anonymous reviewers for comments regarding the manuscript. This study was partially funded by the United States Department of Agriculture CSREES Grant No. 2002-38808-01381.

\section{LITERATURE CITED}

Frelier PF, Sis RF, Bell TA, Lewis DH (1992) Microscopic and ultrastructural studies of necrotizing hepatopancreatitis in Pacific white shrimp (Penaeus vannamei) cultured in

Editorial responsibility: Timothy Flegel,

Bangkok, Thailand
Texas. Vet Pathol 29:269-277

Frelier PF, Loy JK, Bray WA, Brumbaugh GW (1994) Status of necrotizing hepatopancreatitis in Texas farmed shrimp, Penaeus vannamei. Gulf Coast Res Lab Spec Publ 1:55-58

Frelier PF, Loy JK, Varner P, Thompson JA, Lawrence AL, Bray WA (1995) Management procedures for the treatment of necrotizing hepatopancreatitis in farmed shrimp. In: Browdy CL, Hopkins JS (eds) Swimming through troubled water. Proc Spec Sess Shrimp Farming. World Aquaculture Society, Baton Rouge, LA, p 240

Johnson SK (1990) Handbook of shrimp diseases. Texas A\&M Sea Grant College Program, Galveston, TX

Jory DE (1997) Necrotizing hepatopancreatitis and its management in shrimp ponds. Aquac Mag Sep/Oct:98-101

Krol RM, Hawkins WE, Overstreet RM (1991) Rickettsial and mollicute infections in hepatopancreatic cells of cultured Pacific white shrimp (Penaeus vannamei). J Invertebr Pathol 57:362-370

Lightner DV (1996) A handbook of pathology and diagnostic procedures for diseases of penaeid shrimp. Department of Veterinary Science, University of Arizona, Tucson, AZ

Lightner DV, Redman RM (1994) An epizootic of necrotizing hepatopancreatitis in cultured penaeid shrimp (Crustacea: Decapoda) in northwestern Peru. Aquaculture 122:9-18

Lightner DV, Redman RM, Bonami JR (1992) Morphological evidence for a single bacterial etiology in Texas necrotizing hepatopancreatitis in Penaeus vannamei (Crustacea: Decapoda). Dis Aquat Org 13:235-239

Lotz JM, Flowers AM, Breland VM (2003) A model of Taura syndrome virus (TSV) epidemics in Litopenaeus vannamei. J Invertebr Pathol 83:168-176

Loy JK, Frelier PF, Varner P, Templeton JW (1996a) Detection of the etiologic agent of necrotizing hepatopancreatitis in cultured Penaeus vannamei from Texas and Peru by polymerase chain reaction. Dis Aquat Org 25:117-122

Loy JK, Dewhirst FE, Weber W, Frelier PF, Garbar TL, Tasca SI, Templeton JW (1996b) Molecular phylogeny and in situ detection of the etiologic agent of necrotizing hepatopancreatitis in shrimp. Appl Environ Microbiol 62: 3439-3445

Pruder GD, Brown CL, Sweeny JN, Carr WH (1995) High health shrimp systems: seed supply - theory and practice. In: Browdy CL, Hopkins JS (eds) Swimming through troubled water. Proc Spec Sess Shrimp Farming. World Aquaculture Society, Baton Rouge, LA, p 40-52

Soto MA, Lotz JM (2001) Epidemiological parameters of white spot syndrome virus infections in Litopenaeus vannamei and L. setiferus. J Invertebr Pathol 78:9-15

Soto MA, Shervette VB, Lotz JM (2001) Transmission of white spot syndrome virus (WSSV) to Litopenaeus vannamei from infected cephalothorax, abdomen, or whole shrimp cadaver. Dis Aquat Org 45:81-87

Vincent AG, Lotz JM (2005) Time course of necrotizing hepatopancreatitis (NHP) in experimentally infected Litopenaeus vannamei and quantification of NHPbacterium using real-time PCR. Dis Aquat Org 67: 163-169

Vincent AG, Breland VM, Lotz JM (2004) Experimental infection of Pacific white shrimp Litopenaeus vannamei with necrotizing hepatopancreatitis (NHP) bacterium by per os exposure. Dis Aquat Org 61:227-233

Zimmerman RJ, Minello TJ (1984) Densities of Penaeus aztecus, Penaeus setiferus, and other natant macrofauna in a Texas salt marsh. Estuaries 7:421-433

Submitted: June 15, 2006; Accepted: February 2, 2007

Proofs received from author(s): March 29, 2007 